\title{
Stieg Trenter - genren och samtiden
}

\section{Av Ulf Carlsson}

\author{
Länk till presentation av Ulf Carlsson
}

Historien i korthet. Under åren 1944-50 utgav Stieg Trenter de sju kriminalromaner som står i centrum för denna artikel och där fotografen Harry Friberg är berättare och huvudperson: Farlig fåfänga (FF) 1944, I dag röd (IDR), 1945, Lysande landning (LL), 1946, Tragiskt telegram (TT), 1947, Träff i helfigur (TIH), 1948, Eld i håg (EIH), 1949, samt Lek, lilla Louise (LLL), 1950. Förstaupplagorna växte stadigt, nådde vid slutet av decenniet 20.000 ex och kompletterades dessutom snart med olika billighetsutgåvor. Trenter åstadkom ett genombrott för den svenska kriminalromanen och följdes i spåren av andra storsäljare inom genren, Maria Lang och Vic Suneson från 40-talets slut, H-K Rönnblom från 1955. Själv kunde han fortsätta sin serie kring Friberg fram till sin död 1967. Den innehöll då sammanlagt 24 romaner, varav de flesta trycktes om på nytt så sent som i slutet av 80-talet.

Trenters kvaliteter är uppenbara vid en jämförelse med hans närmaste svenska föregångare, sådana som Sture Appelberg, Yngve Hedvall, Torsten Sandberg, Gösta Pettersson och Kjerstin Göransson-Ljungman. Hans stil är avsevärt smidigare, hans känsla för kriminalberättelsens rytm överlägsen någon av dessa ganska tungfotade författare. Hans Stockholmsskildringar har en sinnlig konkretion som ofta prisats av eftervärlden. I Harry Friberg har han funnit en engagerad och skiftande berättarröst, dessutom ett redskap för återkommande värdering av samtiden.

Stieg Trenter är på så sätt ett av många exempel på hur genrens konventioner framgångsrikt anpassats till nationella omständigheter. Men han är också intressant därigenom att han börjar sin romanserie i ett övergångsskede, när pusseldeckaren à la Agatha Christie både modifieras och får konkurrens av andra typer av kriminallitteratur. Trenters 40-talsproduktion visar i och för sig inga spår av vare sig Raymond Chandlers s.k. hårdkokta deckare eller Georges Simenons polisromaner, men samtidigt som han bevarar pusseldeckarens koncentration på gåtan avviker han från dess mönster i flera andra avseenden.[1]

Till skillnad från självmedvetna genier som Sherlock Holmes eller Hercule Poirot är Trenters hjälte Friberg en vardaglig människa, förankrad i sina civila arbetsuppgifter. Berättelserna tilldrar sig i en storstad präglad av modernitetens tempo och konflikter, inte i de enstaka överklassresidens eller den bymiljö som mellankrigstidens engelskspråkiga deckarförfattare gärna sökte sig till. Trenter visar också en påfallande dragning till sedeskildringen, ställer modernitet mot tradition och utnyttjar brottshistoriens emfas till att peka ut dygder och laster hos den expansiva svenska efterkrigstidens medelklass och borgerlighet.

Min läsning av Trenters tidiga romaner - med tonvikt på den första, Farlig fåfänga koncentreras på texternas förhållande dels till genretraditionen, dels till samtiden och dess ideologiska klimat, och behandlar romanerna utifrån fem centrala komponenter: "Hjälten", "Miljön och tiden", "Gåtan", "Utredningen" och "Skulden". Läsningen har samtidigt sin utgångspunkt i en kritisk diskussion av genreteoretikernas föreställningar om kriminalromanens entydiga ideologiska karaktär. I teoribildningen har texterna gärna uppfattats som bestämda dels av genrens normer, dels av en strävan att fungera ensidigt betryggande eller bekräftande gentemot rådande värderingar. Jag vill istället föreslå en läsning som i högre grad beaktar de spänningar som uppträder i texterna: genrens mönster 
kan strida mot varje form av ideologisk bekräftelse; den ideologi som präglar texten behöver inte vara alltigenom enhetlig.

\section{Genren och ideologin}

Försöken att tilldela kriminalromanen eller dess subgenrer en entydig ideologisk karaktär återkommer hos flera teoretiker. Ett utslag av vad som inom marxismen brukar betecknas som "ekonomism" står Ernest Mandel för: "Det är just på grund av att den klassiska detektivromanen skildrar de triumferande rentierernas härskarklass strax före och strax efter 1914 i de anglosaxiska länderna [...] som brottsskildringen kan bli så utomordentligt schematisk, konventionell och konstlad". Och: "Reduceringen av brott till 'mordgåtor' som kan lösas är symboliskt för en beteendemässig och ideologisk trend som är typisk för kapitalismen".[2] "Överbyggnaden", däribland ideologi och konst, blir en enkel reflex av produktionsförhållandena. Man kan invända att gåtan kring det enskilda brottet mycket väl kan bestå som textens centrala element, men samtidigt kombineras med starkt samhällskritiska inslag, hos hårdkokta författare som Raymond Chandler eller Ross Macdonald liksom hos sentida svenska företrädare som Maj Sjöwall och Per Wahlöö eller Henning Mankell.

John G. Cawelti vill i sin Adventure, Mystery and Romance. Formula Stories as Art and Popular Culture förklara pusseldeckarens genombrott i sent 1800-tal med en kombination av sociologiska och djuppsykologiska hypoteser kring den angloamerikanska medelklassen. Genom att mordet ofta skedde mitt i familjekretsen svarade det mot läsarens latenta fientlighet mot sina närmaste, i sin tur resultatet av en strikt och kravfylld uppfostran. Genom att brottet individualiserades och förvandlades till ett pussel, ett spel, behövde det inte ses som ett hot mot samhällsordningen eller som ett allvarligt socialt och moraliskt problem.[3]

Redan förutsättningen att mord inom familjens snäva cirkel dominerar till den grad är tvivelaktig. På ett generellt plan underhåller pusseldeckaren en misstro inte exklusivt mot familjen - det är t.ex. sällan som barn mördar föräldrar eller vice versa, något som sannolikt kan skyllas underförstådda tabun - utan snarare mot den bredare gemenskap som den egna sociala gruppen eller klassen utgör. Cawelti beskriver också genrens effekter på ett sätt som erinrar om det "falska medvetande" som inom vissa grenar av marxismen kommit att definiera ideologin. Sannolikt överskattar Cawelti fiktionens förmåga att effektivt undantränga en verklighet som, poängterar han, samtidigt var moraliskt besvärande och skuldladdad för medelklasspubliken. Bilden av läsarna kommer hos Cawelti att ligga i linje med envist återkommande idéer om populärkulturens lättmanipulerade konsumenter.

Stephen Knight menar i Form and Ideology in Crime Fiction att kriminalromanerna både förverkligar och bekräftar en hel världssyn som kan delas med publiken, en världssyn som dessutom är tilltalande och betryggande. Edgar Allan Poes och Arthur Conan Doyles hjältefigurer, de geniala detektiverna Dupin och Sherlock Holmes, får sålunda till uppgift att bemästra en värld som ter sig osäker och farofylld för läsarna. Knight talar om Londons ängsliga, alienerade, uppåtsträvande tjänstemän som den läsekrets Doyle kom att rikta sig till. Vad gäller Agatha Christie och hennes publik betonar han däremot den kollektiva säkerheten hos en klass i en speciell epok och hur väl de intrikata pusselgåtorna samspelar med självuppfattningen hos en välmående, respektabel, ofta arbetsfri medelklasspublik, som ges möjlighet att tävla med Hercule Poirot på lika villkor.[4]

Bilden av såväl Doyles som Christies publik är svagt underbyggd och delvis, erkänner Knight, konstruerad utifrån romantexterna.[5] Man kan med visst fog vända på den och förutsätta att läsarna i sekelskiftets mäktiga Brittiska Imperium kunde känna en större trygghet än de som på 20- och 30-talet hade upplevt första världskriget och kom att uppleva den stora depressionen. Ernest Mandel t.ex. menar att mellankrigstidens pusseldeckare kännetecknas framförallt av nostalgi, av längtan tillbaka till den stabilare ordningen före 1914.[6] Man behöver inte heller förutsätta att texterna så fullständigt svarar mot läsares upplevelse av sin tillvaro. Till deckarförfattarens basala uppgifter hör att ge 
läsarna den spänning man mera sällan träffar på i sitt personliga liv. Inga kriminalromaner klarar sig utan ett mått av suggererat hot, de kan svårligen vara enbart betryggande.

Det finns däremot ingen anledning att överge Knights och Caweltis grundläggande antagande om en stark anknytning mellan pusseldeckaren och medelklasspubliken. Det empiriska materialet är visserligen bristfälligt. Cawelti hänvisar till slumpartade observationer, som i sin tur visar sig överensstämma med t.ex. författaren R. Austin Freemans brevväxling med sin läsekrets.[7] Viktigare är emellertid att åtskilliga inslag i texterna kan sägas rikta dem mot i första hand medelklassen. Medan arbetarklassen är närmast utesluten tillfredsställer romanerna gärna en nyfikenhet på överklassens seder; hjälten-detektiven förkroppsligar, som Knight betonar, en individualism som är framträdande i olika varianter av medelklassideologi; inte minst ter sig bilden av hur brottet alstras inom den egna gruppen ägnad att underblåsa rädslorna inom en klass präglad av inbördes konkurrens.

Ytterligare en teoretiker, Dennis Porter, utgår i The Pursuit of Crime. Art and Ideology in Detective Fiction från att kriminalromanen bereder sin läsare njutning, och att inslagen av stark spänning är en del av denna njutning. Läsningen jämförs med en bergochdalbanefärd som likaledes innehåller löftet om en återvändo till tryggheten. Samtidigt menar Porter att genren som helhet måste beskrivas som "a literature of reassurance and conformism". Kriminalromanen ställer fram en välordnad värld där inslagen av ondska går att förklara. Den bedriver dessutom sitt spel efter etablerade regler och för det till ett positivt slut - "a sense of mechanistic inevitability is communicated that has the reassuring force of a law".[8] Framförallt anknyter genren dels till en övergripande ideologi inriktad på hjältedyrkan, dels till nationella myter som bekräftas via detektivens karaktär. Sherlock Holmes representerar då den aristokratiskt färgade livsstil och de heroiska kvaliteter som engelsk övre medelklass gör anspråk på under Imperiets glansdagar. Dashiell Hammetts och Chandlers hårdkokta privatdetektiver tillhör däremot en folklig tradition med rötter i erövringen av den amerikanska västern - de företräder den lille mannen som enbart har sin egen tuffhet och heder att tillgå i en civilisation som förvandlats till en mardröm.[9]

De patriotiska drag som Porter urskiljer i dessa gestalter och i Simenons Maigret kan han emellertid inte med samma relevans knyta till Christies Poirot eller Sayers Lord Peter Wimsey, som båda beskrivs som utslag av genrens tendenser till "self parody".[10] Porters strävan att se kriminalromanen som underordnad en konformistisk och nationellt sinnad ideologi möter här svårigheter som hör samman med genre och litterär teknik. Man kan hävda att samma problem uppträder också ifråga om Holmes och Chandlers Marlowe, karaktärer som båda är så sammansatta att inslaget av nationell myt kompliceras: hos Holmes av det romantiska geniets mörka sidor, hos Marlowe av den desillusionerade intellektuelle. Polismannen Maigret, faderligt välvillig och folklig i sina vanor, ter sig däremot som ett bättre exempel både på nationell förankring och på att genren kan stärka tilltron till nationalstatens förmåga att upprätthålla lag och ordning.

Ett alternativ till genreteoretikernas antaganden om kriminalromanens entydiga ideologiska karaktär ger de teoretiker som istället menar att skönlitterära texter generellt rymmer en spänning mellan ideologins och litteraturens olika krav. Pierre Macherey bygger i Theory of Literary Production på den tidige Althusser och dennes syn på ideologin som en "falsk totalitet", avsedd att dölja verkligheten och utplåna alla spår av självmotsägelse och därför oförmögen att se sina egna gränser. Litteraturen däremot, skriver Macherey, inte utan idealistiska övertoner, hånar varje troskyldig syn på världen och utmanar ideologin genom att använda den.[11] Terry Eagleton invänder mot Macherey i sin Criticism and Ideology dels att ideologier i olika grad bär element av verklighet inom sig - de är inte alltigenom "falska" - dels att skönlitterära texter skiljer sig ifråga om sin öppenhet gentemot ideologier. Kristet eller stalinistiskt präglade texter tillåter exempelvis ideologierna att inträda i förhållandevis "ren" form.[12] Icke desto mindre ser också Eagleton den litterära texten som "relativt autonom" i sitt förhållande till den ideologi den trots allt är kopplad till. I motsats till Macherey utesluter heller inte Eagleton att en text kan uppvisa ideologiska konflikter.[13] 
Det finns hos Eagleton en tydlig diskrepans mellan å ena sidan hans ambition att systematiskt beskriva förhållandet mellan ideologi och text, å den andra de svårigheter som uppstår med ett begrepp som aldrig blir tillräckligt definierat och som med hans egna ord är teoretiskt inadekvat.[14] Hos den senare Eagleton, bl.a. i essän "Form and Ideology in the Anglo-Irish Novel", finner man däremot analyser som på ett ledigare, om än mindre teoretiskt anspråksfullt, sätt belyser spänningarna mellan ideologi och text. Eagleton poängterar där gång på gång att "imagination" kan komma i konflikt med "ideology", "form" med "moral content", "naturalist fidelity" med "political intent".[15] Texten tillkommer i ett kraftfält av olikartade traditioner, estetiska och politiskt-ideologiska.

Eagleton har också i sin Ideology. An Introduction utrett ideologibegreppets mångtydighet. Han ser där användbarheten i flera, ömsesidigt uteslutande definitioner, men varnar samtidigt för att begreppet kan förlora i skärpa om det tillåts expandera dithän att praktiskt taget allt tillmäts ideologisk betydelse.[16] Den innebörd som jag fortsättningsvis avser under diskussionen av Trenters romaner är traditionell och dessutom begränsad till sin omfattning. Med Jorge Larrains ord handlar det om "political ideas, discourses and worldviews which are articulated around some principles related to the interests of some social group, party or class".[17] Ideologier tjänar den egna gruppens intressen och avgränsar gentemot andra. Av definitionen följer däremot inte att ideologi är något som uteslutande används av den styrande klassen i ett samhälle, en idé som emellanåt framträder i litteraturen.[18] Såväl maktägande grupper som de i underläge kan utforma sin egen ideologi. Definitionen medger samtidigt att enskilda idéer, kring t.ex. skötsamhetens eller den egna nationens värde, inte behöver vara exklusivt tillhöriga en enda klass eller grupp. Att ideologier på detta och andra sätt har en grad av självständighet innebär i sin tur inte att de helt förlorat sin anknytning till klassens snäva materiella intressen.

Det finns all anledning förutsätta att också populärkulturella texter som kriminalromaner kan präglas av mera komplexa förhållanden än de där texten är inordnad under ett visst ideologiskt mönster. Först och främst tjänar kriminalromanen generellt inte bara till att bekräfta läsarens föreställningar om samhällssystemets effektivitet, att lag och rätt kan upprätthållas och skulden definitivt fästas vid en enskild. Den har också till uppgift att vidmakthålla en misstro mot karaktärerna och understryka en komplikation och dubbelhet som har svårt att samstämma med ideologisk förenkling. Mot strävan att med olika grepp betona det socialt och moraliskt önskvärda står möjligheten att förstärka bilden av mänsklig opålitlighet och ett instabilt samhälle. Sådana tendenser har blivit alltmer framträdande i genrens senare utveckling, men inte ens pusseldeckaren med dess närhet till medelklassen behöver förstås som alltigenom bestämd av en enhetlig ideologi - snarare kan texterna dramatisera och bearbeta motsägelsefulla inslag i en världsbild. Detta utesluter inte att genren också innehåller exempel som kan sägas överta en ideologi i den "rena" form Eagleton talar om.

För det andra har kriminalromanen en estetisk egendynamik inriktad på att variera inte bara mordproblemen utan också persongalleri och miljöer. Genren är visserligen starkt uppknuten till nedärvda konventioner, men har samtidigt genom hela sin historia demonstrerat sin förmåga till förnyelse och breddning av slitna mönster. De estetiska tekniker som har tagits i bruk kan knappast i varje given situation förutsättas överensstämma helt med ideologiska krav. Istället uppträder de parodiska inslag Porter observerat hos t.ex. Christie, de komplikationer i karaktärsteckningen man kan finna hos Doyle och andra, eller den sammansatta bilden av storstaden hos Simenon och Chandler. Texterna öppnar sig därigenom för olika läsarter.

\section{Samtiden}

Det ideologiska landskap där Stieg Trenters romaner tillkom präglas framförallt av folkhemsandan med dess betoning av en bred nationell gemenskapskänsla. Per-Albin Hanssons valseger och krisuppgörelsen 1933 lägger grunden för en stark och reforminriktad regeringsmakt. Med "folkhemmet" som retorisk ledstjärna börjar det 
moderna välfärdssamhället växa fram. "Den svenska modellen" inriktas mot samförstånd och kompromiss, på arbetsmarknaden såväl som i parlamentet, och kännetecknas av täta kontakter mellan socialdemokrati och storkapital. Krigsårens starka krav på nationell enighet, medborgaranda och samhällsansvar och dess åsidosättande av partiskiljande frågor ligger sedan i linje med en redan etablerad politik.

Bilderna av 30-talet, hos etnologer, historiker och andra forskare, framhåller tilltron till den moderna utvecklingen och till möjligheterna att överbrygga det förgångnas klassklyftor och bygga en gemensam framtid i svenskhetens tecken. Samtidigt beskrivs det nationella identitetsbygget på något olika sätt, med tonvikt antingen på det folkliga eller det elitära inslaget i processen. Orvar Löfgren vill i sin "Nationella arenor" framhålla den "emancipatoriska" sidan och menar att "folk under 1930-, 40- och 50-talen gjorde sig svenska snarare än gjordes".[19] Yvonne Hirdman däremot annonserar redan via titeln på sin bok Att lägga livet till rätta ett annat perspektiv. Ambitionen att vända förlegade traditioner och styra människor som inte förstod "sitt eget bästa" visade sig inte minst i den s.k. sociala ingenjörskonsten och dess försök att normera livssektorer som tidigare uppfattats som privata - bostäder, arbetsdelning inom familjen, t.o.m. sexualiteten. Toleransen gentemot avvikarna minskar, något som blev tydligt i steriliseringslagstiftning och diskussionen kring "Lort-Sverige".[20]

Kombinationen av elitär styrning och folkligt engagemang liksom de starkt framträdande dragen av samförståndsanda och nationell värdegemenskap gör det frestande att beskriva det dåtida Sverige utifrån hegemonibegreppet sådant som det myntats av Antonio Gramsci och utnyttjats av bl.a. Raymond Williams och Stuart Hall. Hegemoni förutsätter hos Gramsci att den politiska och ekonomiska makten är beroende av de maktägande skiktens förmåga att etablera en ideologisk samsyn som accepteras också av de styrda. Individer binds till samhällssystemet, inte i första hand med tvång utan via samtycke. Hegemonin får fördenskull inte uppfattas som resultatet av någon ideologisk manipulation från en styrande elit - den bygger enligt Gramsci istället på en politisk blockbildning bortom de utpräglade klassintressenas ram.[21] "Motståndarlägren" inordnades "i en gemensam syn på utvecklingen", skriver Mikael Stigendal med avseende just på Per-Albin Hanssons folkhemspolitik som ett exempel på hegemoni.[22] Den svenska modellen i dess fullgångna skick under efterkrigstiden har också lockat till samhällsvetenskapliga analyser med utgångspunkt hos Gramsci.[23]

Samtidigt är "hegemoni" en besvärlig term, mångtydig redan hos Gramsci och därefter utvecklad i flera olika riktningar.[24] Det finns även hos en varsam teoretiker som Raymond Williams en tendens att tänja begreppet i så diametralt motsatta riktningar att det dels förlorar sin pregnans, dels kan användas för att beröva kulturen all självständighet i förhållande till samhällssystemet.[25] Då hegemonibegreppet ter sig användbart för att beskriva den svenska utvecklingen alltifrån 30-talets början, handlar det alltså inte om att ange, som Hall skriver, "one, single, unified and coherent 'dominant ideology' which pervades everything" utan om att understryka styrkan och omfattningen i de ideologiska tendenser som betonade en klassöverbryggande värdegemenskap.[26] Dessa tendenser skall då inte uppfattas så, att de utesluter traditionella, särskiljande och framförallt klassbaserade perspektiv. Jonas Frykman och Orvar Löfgren menar t.ex. att 30-talet präglas av "individens samhälleliggörande. Individen förs fram ur kollektivet för att så förstatligas som medborgare", men vänder sig samtidigt mot föreställningar att "klasserna anpassade sig till varandra och [...] den sålunda uppkomna minsta gemensamma nämnaren blev allas riktmärke för dagligt liv och arbete".[27]

Även krigsårens samlingsregering hade att bakom fasaden hantera en rad besvärliga kontroverser olika särintressen emellan.[28] Under efterkrigsperioden trädde sedan flera konflikter i öppen dager. Den stora metallstrejken 1945 avslöjade motsättningar inom arbetarleden vad gällde tilltron till samförståndspolitiken. Åren efter krigsslutet präglades därtill av den s.k. planhushållningsdebatten, en period av borgerlig kamp mot socialdemokratiska strävanden att bredda den statliga styrningen av ekonomin. Yvonne Hirdman har visat hur folkhemsingenjörerna mötte motstånd också inom socialdemokratin 
där frågan om kvinnans framtida roll i hem och yrkesarbete blev en stötesten. Kritiken mot den moderna utvecklingen kom ofta till uttryck i samtidens offentliga diskussion, mest spektakulärt kanske redan i krigsårens moraliska panik kring "dansbaneeländet" och ungdomens förmenta normlöshet.[29] Spänningen mellan stad och landsbygd underhölls av jordbrukets avfolkning och ekonomiska svårigheter, något som i sin tur avspeglade sig i en lång rad filmer och romaner.[30] Inom ramen för en fortsatt stark folkhemsideologi rymdes på så sätt också konflikt och osäkerhet.

\section{Hjälten}

Farlig fåfänga, Trenters första roman om Harry Friberg, inleds med att denne sitter på restaurang Cattelin i Gamla Stan, vill beställa sniglar men får nöja sig med kalvhjärna, franska assietter och en halvflaska Vino Rosso. Friberg som gourmet med en faiblesse för det internationella köket ger en första antydan om hans karaktär - han har bestämda preferenser på de flesta områden och ges rikligt med tillfällen att formulera dem. Bilden av den exklusive finsmakaren ställs emellertid i nästa stycke mot en av flit och framgång. "Jag hade verkligen arbetat hårt. Det kunde jag utan skryt säga", försäkrar Friberg och väger blygsamhet mot strävan att göra sina utsvävningar acceptabla. Som fri företagare har han belönats med "rekordomsättning" och kunnat utöka sin personal. Uppenbart en man som deltar i ett svenskt framtidsbygge tänker han nu unna sig semester, gå på Solvalla och revy och besöka saluhallen på Hötorget (FF, s. 5f).

I sitt förhållande till genretraditionen bär konnässören Friberg på en touche av den särprägel som utmärker en Holmes, en Poirot eller den gastronomiskt exklusive Nero Wolfe, Rex Stouts huvudperson, men den underordnas omedelbart respekten för socialt accepterade dygder som plikt och skötsamhet och förenas med en förtrolig närhet till läsarna. Han är en i den värdegemenskap han riktar sig till, en Watson snarare än en excentrisk Holmes, bara aningen mera profilerad och inte fullt lika bastant förankrad i samhällets konventioner, en medelklasshjälte i en genre vars tydliga medelklasskaraktär ofta har betonats.

Arbetsamhet och förmåga till livsnjutning. Inledningsscenen beskriver en välförtjänt avspänning, den inbjuder läsaren att på motsvarande sätt retirera från vardagens krav och gå in i den förströelse som romanens värld kan ge. Liksom så ofta inom genren präglas anslaget av harmoni.[31] Vi kan möta Friberg på den "trivsamma" krogen, så även i Eld $i$ håg, i kamratligt samspråk med någon av sina anställda i Lek lilla Louise, eller på väg in i Centralbadets tillflykt undan jäktet i Tragiskt telegram. Huvudpersonen själv anger möjligheterna för denna harmoni; redan här tilldelas han en position han skall behålla 40talsromanerna igenom, som ett exemplariskt mönster vars måtta och sans - "en halvflaska Vino Rosso" - självklara arbetsmoral och optimism kontrasteras mot karaktärer som istället saknar denna balans och söker nå framgång utan ansträngning, njutning utan självdisciplin.

Harmonin kommer att rubbas av brottet, men samtidigt ger romanerna också utrymme för vilopunkter, inslag som likaledes framhäver en social normalitet. I Farlig fåfänga handlar det om ett konserthusbesök tillsammans med mordoffret Paul Groths syster Lena, därtill några idylliska scener med Lena och Friberg i en tillfällig föräldraroll gentemot barnhusflickan Marianne. I romanseriens fortsättning återkommer framförallt de avbrott i undersökningarna där Friberg och kommissarien Vesper Johnson njuter varandras sällskap i en aningen labil förbrödring.

Fribergs företagsamhet lönar sig allt bättre - vilket vi blir noggrant underrättade om i varje roman. Han omger sig med en växande skara medarbetare i sin ateljé, ger ut fotoböcker, får internationella uppdrag och bemöts efterhand som en smärre celebritet. Aldrig beklagar han sig över några svårare hinder på en till synes obegränsad marknad, utan fogar sig istället till de "grabbar med framåtanda" som var frekventa redan i den svenska 30talsfilmen.[32] 1947, i Tragiskt telegram, låter Trenter honom dessutom bege sig på semesterresa ut i det Europa som nu på nytt lockar svenska turister och vi får följa Fribergs upplevelser av Paris och italienska Rivieran. Romanserien är alltså till dels en 
framgångssaga, men det är ständigt framgång garderad med omdöme. Friberg skaffar sig egen bil i den tredje romanen, byter sedan upp sig men är fortfarande 1950 tillfreds med den anspråkslösa vagn han omtalar med barnslig förtjusning som "Mr. Hillman". Trenters karaktär är inte bara i takt med tiden, utan också med medelklasspublikens förväntningar på vad utvecklingen rimligen kan medföra för deras privata del.

Friberg är "en vanlig, hederlig kille" skriver Jörgen Elgström och Åke Runnquist i den första större översikten över svensk kriminallitteratur, Svensk mordbok från 1958.[33] Vid närmare granskning ter sig Friberg som en väl avvägd kombination av individualism och konformism, modernitet och tradition, folkhemsvärden och medelklassdistinktion. Utifrån denna position fungerar han också som ett ständigt värderingsinstrument i texten, mot de karaktärer han möter men också mot olika tendenser i samtiden. Medan Friberg själv visar avslipade umgängestalanger kan han reagera mot folk inom samma sociala skikt som däremot är "ytliga, trångsynta och oartiga" (LL, s. 43). Han får ofta demonstrera sin empati och ter sig föredömlig som modern arbetsgivare, utan auktoritära drag, klassfördomar eller behov att markera sin status. Ur ett perspektiv kan på så sätt bilden av Friberg ses som ett uttryck för den hegemoniska folkhemsideologins starka betoning av samförstånd och klassöverskridande.

Mot detta står Fribergs utpräglade medelklassidentitet, hans framtoning av "kultiverad" människa sådan som denna idealtyp beskrivits av etnologerna.[34] Han sprider inte bara synpunkter på de bättre Stockholmskrogarnas menyer, utan är överhuvudtaget väl rotad i en traditionell borgerlig kultur. Till de fåtaliga upplysningarna om hans bakgrund hör att han gått igenom läroverket och spelat tredjefiol i skolorkestern. Han hyllar Beethoven och Mozart, är bekant med Poes och Shelleys lyrik och kan jämföra med italiensk renässanskonst då han möter en kvinnlig skönhet. Ofta får han ondgöra sig över skrikiga modernistiska målningar, över jazz eller över den nutida dansmusik han betecknar som "oväsen" (FF, s. 183). Funkishusen på Gärdet är honom lika främmande som modernistisk trädgårdsarkitektur (IDR, s. 121, TT s. 6). Tendenserna till snobbism motvägs å andra sidan av att han heller inte föraktar att besöka korvkiosken eller ta en pilsner i gröngräset och han följer idrottshändelserna med intresse.

Trenters hjälte är ungkarl, bor i en prydlig lägenhet vid Brunkebergstorg och underhåller enbart sporadiska kontakter med en syster och en faster. Några föräldrar omtalas överhuvudtaget inte. Friberg är även på så sätt ett med sin samtid, obunden av det förflutna. Vad gäller privatmoralen visar han emellertid en självkontroll och återhållsamhet som i någon mån kan uppfattas som tidskritisk. Visserligen får han avslöja ett tydligt erotiskt intresse för de kvinnor han kommer i kontakt med, men han är samtidigt ridderlig och närmast kysk i sitt förhållande till det motsatta könet, en kavaljer av taubesk karaktär. Vid upprepade tillfällen avvisar han inviter från olika damer. Ett nattligt samtal i hans egen bostad med en skrämd kvinna slutar med att han skjutsar henne hem, detta sedan de enats om det "opassande" i att hon sover över på hans soffa (LL, s. 170). Han ändrar också sin sedesamt negativa bedömning av en kärlekshistoria sedan han fått veta att paret faktiskt förlovat sig (LLL, s. 162). Samtidigt tilldelas Friberg en närmast terapeutisk roll, blir till den som avlyssnar olyckliga människors livshistorier och låter dem på så sätt förevisa sexualitetens många blindskär. Mot denna bakgrund kommer det som en smärre chock när han i slutet av den sjunde romanen, Lek lilla Louise, till sist ändå utväxlar en kyss med en av de misstänkta - det blir dock aldrig mera (LLL, s. 199). Romanerna ställer denna försiktighet mot en hel serie exempel på misslyckade äktenskap, sexuell vidlyftighet och hänsynslösa utnyttjanden av kärlekspartners.

Friberg fyller på så sätt väl sin exemplariska uppgift, på en gång bejakande inför det nya samhället och kritiskt vaksam mot dess överdrifter, en företrädare för en framtidssinnad medelklass vars initiativrikedom kombineras med kulturell polityr, traditionskänsla, moraliskt ansvar och tolerans. Frykman och Löfgren har poängterat att medelklassen blir det förebildliga och normala i trettiotalets samhälle, riktningsgivaren mot den framtid där fattigdom och okunskap har fått ge vika och där varje individ ges möjlighet att - och bör tillvarata sin begåvning. Men Trenters och Fribergs modernitetskritik kan å andra sidan ses 
mot bakgrund av ambivalensen i en social position: den medelklass som upphöjs till ideal känner samtidigt sin nedärvda ställning hotad, på arbetsmarknaden men inte minst inom kulturen.[35]

Påfallande är också snävheten i Fribergs värderingar liksom hans närmast ängsliga balansgång mellan individualism och anpassning. Åke Daun menar att en egenartad form av konformitet kännetecknar det moderna samhällets "svenska mentalitet" överhuvudtaget. Alla skall vara oberoende och självständiga men ändå dela samma värden.[36] Yvonne Hirdman beskriver målet för 30-talets folkhemspolitik som "en 'människotyp' som var både självständig och socialt anpassad, en smidig och begåvad individualkollektivist".[37] Alf W. Johansson menar i sin tur att "[d]en svenska modellen byggde på en inifrånstyrd individ: samvetstyngd och skuldmedveten [---] Puritanismen blev en tyst kunskap, en ickediskuterad förutsättning för samhällslivets sociala former". [38] Folkhemmet kunde härvidlag bygga på de starka skötsamhetsideal, som bl.a. Ronny Ambjörnson betonat, och som präglade breda skikt av både medelklass och arbetarklass och krympte marginalerna för individuell särprägel.[39]

Trenters romaner ligger väl i linje med tendensen att granska och bedöma den enskilde utifrån en förment normalitet, inte minst då brottsfallen ger Friberg tillfälle att betygsätta ett urval interiörer vad gäller smak och allmän ordning. Farlig fåfänga innehåller halvdussinet sådana hemma-hos-besök och mönstret är sedan genomgående i serien. Berättaren får agera skötsamhetens och måttlighetens apostel, noterar småaktigt de kantstötta kaffekopparna hos en annan och slarvigare ungkarl - "Inte ens skedarna var maka" - men beskärmar sig också över de nyrikas excesser. "Det pris dessa solstolar betingade översteg säkerligen vida den summa ett ordinärt nygift par har att spendera på hela sitt hem", anmärker han vid ett besök i överklassen (LL, s. 68, 122).

\section{Miljön och tiden}

Trenter publicerar 1944 en spionthriller, Som man ropar, om naziagenters framfart i beredskapstidens Sverige. Med Farlig fåfänga från samma år riktar han emellertid fokus bort från det yttre hot som vid tiden för Normandie och offensiverna på östfronten definitivt har lättat. Beredskapen - ett alltför väl bearbetat ämne i den samtida filmen - är också närmast demonstrativt frånvarande i romanen. Berättelserna om Friberg kommer istället att koncentreras till de inre konflikter som kan framträda då den påtvingade nationella samlingen ger vika och öppnar ett annat utrymme åt den enskilde. Fienden finns nu "mitt ibland oss". En kriminalgåtans förutsättning i Farlig fåfänga liksom i tidigare pusseldeckare är att mördaren ryms inom den snäva cirkel som här utgörs av släktingar, vänner och affärskontakter kring offret.

Den värld vi möter i romanerna blir tidigt socialt avgränsad. Från matsalen på Cattelin ser Friberg ut mot "den mörka bierstugan" med dess grova träbord och urskiljer "hamnsjåare" och "två bedagade och bemålade damer". En enda blick, sedan återvänder hans intresse till "ett helt annat slags människor" som vistas i de dyrare lokaliteterna (FF, s. 6). Passagen kan tolkas som en försäkran. Läsaren kommer att besparas indignation över klassamhällets orättvisor eller de prostituerades sorgsna livslott, framträdande motiv i 30-talets arbetarlitteratur. Med en gängse term inom ideologikritiken "naturaliseras" istället det urbana medelklassperspektiv som från första ögonblicket bestämmer Trenters texter och blir aldrig ifrågasatt av några alternativa eller kritiska röster.[40] Samhällssystemet är en outtalad förutsättning, den entusiastiske och rättrådige Friberg visar på dess möjligheter men finner också att dess spelregler kan överträdas.

Men passagen blir också ett möte mellan romanens ansats till bred samtidsskildring och de klassgränser som genrekonventionerna drar upp. De sociala skikt som är närmast osynliggjorda i mellankrigstidens pusseldeckare får för ett ögonblick framträda och sedan återvända till glömskan. Simenons intresse för människoöden i marginalen blir inte Trenters. Å andra sidan vidgar romanerna den trånga överklassfären i pusseldeckaren. Intrigerna koncentreras förvisso till borgerlighetens interiörer, men dessa tillhör i sin tur en 
större arena, det stockholmska stadslandskap där Friberg rör sig fram och åter, registrerar gatulivet och miljöernas mångfald, och tillfälligt möter människor i olika sociala positioner. Trenters egenart ligger inte minst i denna strävan att behålla det begränsade rum som den intrikata gåtan traditionellt kräver och samtidigt ge romanerna modern storstadsatmosfär.

Romanerna om Friberg suggererar bilden av ett skiftande och rörligt samhälle. Samtidigt sker detta via en medelklassindividualism som aldrig konfronteras med det äldre samhällets hårda klassattityder, men ändå avskiljer huvudpersonen från de anonyma "kontorsslavar" han observerar på spårvagnarna (FF s. 134, IDR s. 7), den "svarta folkhop" som trängs utanför biografen (TT s. 17) och de fattigmiljöer på Söder han sporadiskt besöker (LL s. 324ff, TT s. 107). Trenters Stockholm innehåller inte heller några som helst påminnelser om folkrörelsernas eller socialdemokratins närvaro. Vid ett enda tillfälle i de sju romanerna träder Friberg i närmare kontakt med karaktärer ur arbetarklassen. Det handlar då om två flygmekaniker i Lysande landning, som med välbalanserad hantering av schablonerna fördelas på var sin sida om lagens och hygienens råmärken. Den ene, Ohlson, är en något naiv men alltigenom renhårig söderkille som blivit "le på att torka lort" på sin arbetsplats och vill bli fotograf, ett exempel på individuell ambition i sann folkhemsanda som Friberg ges tillfälle att uppmuntra (LL, s. 298). Den andre, Brisman, är däremot en svartmuskig och opålitlig tjuv som skrytkör en Mercedes, men vars bostad blir till en skräckbild av unken osnygghet. Icke desto mindre visar han sig till sist oskyldig till de två mord han misstänks för. Textens centrala roller är förbehållna andra samhällsskikt.

Stockholm hade under de fyra år som gått "hunnit bli nästan en ny stad för mig", säger Friberg (FF, s. 6). Huvudstaden kom under 40-talet att växa snabbare än någonsin i sin historia - folkmängden ökade med 27\% eller 214.000 invånare.[41] Hos Trenter märks emellertid föga av dessa nyligen inflyttade eller av det främlingskap som uttrycks av t.ex. Lo-Johansson, Moberg eller Fridegård på 30-talet. Trots de konflikter som beskrivs får staden istället äventyrets lockelse, den blir en delvis okänd miljö som Friberg upptäcker och fascineras av. Med undantag för den halva av Tragiskt telegram som utspelar sig på kontinenten och för de delar av Eld i håg som är förlagda till Göteborg, koncentrerar Trenter också genomgående sina romaner till Stockholm.

Landsbygden blir föremål för en enstaka utflykt eller omnämns i resuméer kring Fribergs yrkesuppdrag, men fungerar inte som ett alternativ till de moderna livsformerna. Samhällsbilden står i skarpaste kontrast till den samtida landsbygdsromantik där kvardröjande "Gemeinschaft" enligt Per Olov Qvist fick spela mot storstaden som ett träsk av synd och girighet.[42] Periferin blir hos Trenter utan intresse. All uppmärksamhet faller på den brännpunkt, där karaktärer prövas och där samhällsomvandlingen i krigets spår träder fram. I Farlig fåfänga återkommer högljudda sprängningsarbeten som dramatisk ljudkuliss till mordhistorien. På Cattelin surrar det "som i en bikupa av olika språk" (FF, s. 6). Stockholm har med kriget blivit en internationell spänningshärd, ett centrum för flyktingar och för utländska makters intriger.

Romanerna får ytterligare angelägenhet genom att de utspelas i läsarens närliggande samtid. Liksom kvällstidningarna och journalfilmen uppger sig Trenter rapportera direkt från det nu som under krigsåren ständigt haft en ödesdiger laddning. Händelserna i Farlig fåfänga äger rum på våren och sommaren 1944, alltså ett fåtal månader innan romanen publicerades. Friberg åker spårvagn i den bilfattiga huvudstaden och möter bostadsbristens vardagliga problem mitt i intrigens centrum. I bakgrunden hörs nyheter från de olika krigsskådeplatserna, berättaren uttalar sin förhoppning om att tyskarna skall ge upp till nästa vår och att han då skall kunna återse London (FF, s. 8). Han markerar sin demokratiska hållning - redan namnet "Friberg" antyder frihetsandan i en tid då det nazistiska hotet ger vika - men dessutom att Europa med den annalkande freden är på väg att stöpas om. Romanserien skall i fortsättningen kretsa kring yrkesgrupper som på olika sätt avlyssnar tidens rörelser, som utnyttjar, rapporterar om och övervakar dess dynamik affärsmän, journalister, konstnärer, författare, poliser. Genomgående finns samma ambition att förankra intrigen i nuet, tydligast markerad i Träff i helfigur, där kungajubiléet 1948 bildar fond åt slutscenerna, och i Eld i håg, där Friberg redan i inledningen läser en 
kvällstidning daterad 17 augusti 1949.

Mitt i sorlet av främmande tungomål på Cattelin hör Friberg en svensk röst, "mörk, fyllig och sällsynt välljudande", en röst tillhörig "en skönhet" (FF, s. 7). Den första signalen från de sociala miljöer huvudpersonen skall vinna insyn i kommer från en kvinna, en gåtfull Mona Lisa-gestalt som skall följas av än mera utpräglat fatala damer, sexuella feberhärdar i romanernas svenska borgerlighet, avskräckande exempel i Trenters betraktelser över samtidens moral. Så småningom känner Friberg igen skönhetens manliga sällskap - Paul Groth, en gammal klasskamrat som nu står på tröskeln till ett genombrott som bildkonstnär.

Liksom fotografen Friberg är Groth en framtidsman, vars begåvning kan komma att belönas av den nya tiden, men i motsats till huvudpersonen präglas Groth av självhävdelse på gränsen till hybris - han förväntar sig att kritiken skall utnämna honom till "Sveriges största målare" (FF, s. 10). Trenter låter berättarens från början kritiska hållning till Groth bekräftas genom samtalet dem emellan. Medan Friberg får demonstrera folkvett, ödmjukhet och självironi ter sig däremot den ohövlige och hejdlöst anspråksfulle Groth, avvikande redan genom sina mörka glasögon och sitt yviga hår, som ett hot mot balansen i denna trångt normerade värld. I romanens nästa steg skall också konstnärens högmod följas av ett bokstavligt och dödande fall utför ett stup vid hans bostad på Fåfängan, möjligen resultatet av en mördares försåt och därmed utgångspunkten för det mysterium som nu ställs i centrum.

\section{Gåtan}

När mordgåtan väl placerats in i texten kommer Trenters romaner att i konventionell ordning varva förhör, undersökningar av bevismaterial och rekonstruktioner av händelseförloppet. Strävan att konstruera en sinnrik gåta kombineras dessutom med spänningsinslag som biljakter, överfall och nya mord, och Harry Friberg blir i flera fall personligen föremål för brottslingens attentat. Tempot är högt, rytmen accentueras av en tät följd av cliffhangers och suggestiva eller förebådande kapitelrubriker. Den narrativa tekniken erinrar starkt om John Dickson Carr, som Trenter också namngivit som en favorit.[43] Morden är ibland ytterst spektakulära - i Träff i helfigur en man iförd urmodig uniform hängande död på en måltavla, i Lek lilla Louise en annan man offret för en primitiv giljotin i ett fönster. Vissa scener, t.ex. en från det gamla telefontornet i Stockholms centrum i Träff $i$ helfigur, ger anledning misstänka en inspiration från Hitchcock som utnyttjade storstadens landmärken på liknande sätt i filmer som Utrikeskorrespondenten och Sabotage. Trenters spionthriller Som man ropar alluderar öppet på just Hitchcock.[44] Trenter undviker emellertid nogsamt sådana inslag som efterhand hade försvunnit ur så gott som varje pusseldeckare med självaktning lönngångar, förklädnadsnummer, sensationella vapen - men som fortfarande var vanliga i mellankrigstidens simplare kriminalromaner.

Brottet och den gåta det ger upphov till accentuerar samtidigt en rad komplikationer i texten, vad gäller berättarrollen men också i bilden av hjälten och den miljö han rör sig i. Trenters och Fribergs Stockholm blir nu inte enbart ett stycke social geografi eller en serie av visuella upplevelser, utan får dessutom karaktären av hemlighetsfullt väsen, ännu en gåta som gång på gång påminner om sin närvaro och stjäl berättarens uppmärksamhet, ibland t.o.m. mitt i vittnesuppgifterna om ett nyupptäckt mordoffer (LLL s. 68f). Ofta får läsaren följa Friberg gata för gata och via hans blick möta vackra Stockholmsvyer, återgivna i Bellmans och Strindbergs efterföljd med livfull impressionistisk teknik och botanisk exakthet. Mot denna insisterande realistiska konkretion står samtidigt strävan att dramatisera skeendet och lotsa läsaren från det tryggt välbekanta in i det främmande och hotfulla. Klimatiska skiftningar - storm och ruskväder - förebådar och ackompanjerar höjdpunkterna i roman efter roman. Dag spelar mot natt, ljus mot mörker. Det "späda lövverket" på Djurgården blir kvällstid "grönskimrande slöjor" (IDR, s. 9), Slusskarusellen en "häxkittel" vars körbanor snor i "en förvirrande dans" (IDR, s. 74, 42), Järngaraget och mosaiska kyrkogården förknippas båda med "underjorden" (IDR, s. 159, LL, s. 174) och 
gatlyktor och neonljus lever "ett glittrande dubbelliv på den våtblanka asfalten" (IDR, s. 176). Staden erbjuder omväxlande njutning och skräck. I sitt förhållande till staden förses också Friberg med en drömmande och poetisk sida, som kompletterar hans kommersiella inriktning och mera utåtvända drag. Trenter ger honom en anstrykning av flanör eller konstnärsnatur som kan försjunka i skymningens clair-obscure eller i de historiskt präglade miljöer staden bjuder.

Fribergs promenad från Danvikstull till Groths ensligt belägna bostad på Fåfängan blir en övergång till ett skräckens främmande landskap. Det sparsamma gatljuset glittrar "som i en dröm", brons "fula järnskelett" ger associationer till "groteska jätteklumpfötter", halvannan kilometer från Stortorget upplever han sig vara i en karg "ödemark". Huset är "vanskapt och oformligt" och dess vardagsrum pryds av Beethovens dödsmask på väggen. Det dödande fallet utför ett femton meter högt stup signaleras med "ett utdraget, avlägset skri", Friberg talar om händelsens "overkliga mardrömslika" karaktär och säger sig flera gånger stå som "förhäxad" inför dess gåtfulla omständigheter (FF, s. 24ff).[45]

De ofta fantasifulla eller gotiskt accentuerade inslagen i Trenters romaner bygger sin effekt på att texten samtidigt ger en övertygande verklighetsbild via traditionella realistiska grepp - referenser till igenkännbara miljöer, ett uppbåd av konkreta detaljer, en förkärlek för ordinära, "sannolika" figurer. "I detektivromanen främmandegörs för läsaren just den värld som han är förtrogen med", skriver Richard Alewyn. "Detektivromanens realism är inte bara en fråga om stil utan också ett fundamentalt element i strukturen".[46] Då Friberg inträder i familjen Groths förstuga återgår också texten till att avbilda en trivial verklighet där "stod en mangel och på mangeln låg ett hopnystat klädstreck och en binge klädnypor. På andra väggen hängde en trasig kofta och en gammal trenchcoat, och på golvet under stod några utgångna skor och ett par gummistövlar". Det är i denna omgivning Friberg möter Lena Groth, som fortsättningsvis skall uppta mycket av hans intresse. I pusseldeckargenren ter hon sig närmast osannolikt vardaglig: "Hon var cendré, liten och spenslig. Hon hade sammanvuxna ögonbryn och en liten besviken mun. Klänningen satt illa och var opressad, kring det glanslösa stripiga håret var en halsduk knuten. Åldern var svår att bestämma. Hon kunde lika gärna vara tjugofem som trettiofem" (FF, s. 32).

Textens skiftningar matchas av polerna i berättaren Fribergs temperament. Å ena sidan är han en noggrann och saklig rapportör, å den andra emotionell och lättanfäktad av stämningar. Strax innan styckets skurk försöker slå till på nytt, grips han av "plötslig oro och beklämning"; vid upplösningen har han hjärtklappning och känner sig "illamående" (FF, s. 183, 246). Böjligheten i berättarens karaktär stimulerar till variation i läsarens perspektiv gentemot texten. En inlevelsefull eller "identifikatorisk" läsning växlar med den "distanserade", kyligt analytiska hållning som den intellektuellt betonade pusseldeckaren i allmänhet förknippats med. Mot de partier där Friberg är direkt indragen i en dramatisk händelseutveckling står sådana där han med pennan i hand genomför omsorgsfulla rekonstruktioner av brottet och utmanar läsarens intellekt.

Särskilt kritiska blir de inslag i texten som kan tänkas rymma avgörande ledtrådar. Fotografen Fribergs visuella uppmärksamhet begagnas emellanåt till en uppräkningsteknik av nära nog strindbergsk karaktär. Så t.ex. vid hans första besök i Paul Groths ateljé:

Det var ett avlångt, rätt rymligt rum med snedtak och ett stort dubbelfönster på långväggen. Här rådde en kunglig oordning. Runt de fläckiga väggarna stod koppar- och zinkplåtar, på stolar och bord låg strödda halvfärdiga dukar, penslar, färgtuber, trasor och klädesplagg. På en slarvigt bäddad ottoman låg en stapel koppartryckspapper mellan två zinkskivor. Ovanför på väggen hängde ett litet porträtt av fru Montell. Med undantag för ett krucifix och några lampetter, som inte hade sett putsmedel på år och dag, var porträttet det enda som prydde väggarna. [---]

Längst in i hörnet löpte några låga hyllor, fullproppade med blänkande stålnålar, burkar, flaskor och låga vita porslinsskålar. På golvet låg en hög svärtade gardintrasor, strax intill stod en stor rostig tryckpress och på andra sidan ett tvättställ. En säregen blanddoft av 
oljefärg, syror och asfalt fyllde rummet (FF, s. 39).

Detaljerna kan uppfattas som bidrag till en atmosfär, till bilden av Paul Groth, eller, som Roland Barthes skriver, till en "realitetseffekt", en illusion av verklighet som fungerar genom massverkan, bortom det litterärt motiverade i varje enskildhet.[47] Men inventariebeskrivningen tillhör också pusseldeckarens obligatorier, dess föreskrifter om "fair play" gentemot läsaren som förväntas granska varje detalj för att finna gåtans lösning.[48] Efter Groths död återvänder också Friberg till samma miljö, nu en bild av det kaos som mordet skapar, men också en utgångspunkt för läsarens jakt efter ledtrådar:

Det var som en virvelvind gått fram här uppe. Stolar och småbord hade vräkts omkull, mattan låg i en hög mittpå golvet, den ena lampetten var nedriven, och i ett hörn låg staffliet mitt i ett virrvarr av färgtuber, penslar och halvfärdiga dukar. En stark lukt, som på något vis var välbekant fyllde rummet. Den hade inte funnits där förut. (FF, s. 54).

Bl.a. Richard Alewyn har poängterat den komplikation som utmärker pusseldeckarens berättarroll. Den vaksamme läsaren "upptäcker att berättaren hemlighåller något för honom", skriver Alewyn. Han kommer "inte heller att tveklöst acceptera de upplysningar berättaren ger honom. Han kommer att med misstrogen uppmärksamhet pröva dem, vad gäller deras tillförlitlighet och fullständighet".[49] Den intellektuellt prövande, misstänksamma läsart Alewyn framhåller bör emellertid inte uppfattas som den enda möjliga. Om Friberg i viss utsträckning är ett instrument i försöken att manipulera läsaren, så ter sig samtidigt Trenters berättarroll annorlunda balanserad än hos föregångarna inom genren, mera inriktad på att förmedla den osäkerhet och skräck som drabbar då den hederliga vardagsmänniskan konfronteras med brottet. Betecknande är t.ex. att Trenter återger mordets brutalitet med en starkare realism än traditionella pusseldeckare, vilka lätt framstår som eufemistiska i sitt förhållande till våldet.

\section{Utredningen}

Harry Friberg kastas in i dramatiska brottsfall, engagerar sig hårt i utredningarna men förblir i de tidiga romanerna en amatör, förbryllad och vilseledd av de många komplikationerna. I Farlig fåfänga får han finna sig i att bli hånad och utnyttjad av polisen och i finalen slagen med häpnad över dess avslöjanden. Hans detektiva insatser är i första hand komiska och tjänar som kontrast till polisens professionalism. Skillnaden är påfallande gentemot den Friberg som redan i de sena 40-talsromanerna i högre grad får bidra till fallens lösning och som på 50-talet har glidit över i en konventionell och kompetent detektivroll.

Både Poe och Doyle använder sig av berättare som saknar förmågan att se de sammanhang som är tydliga för den store detektiven. Teoretikerna har menat att tekniken innehåller framförallt två förtjänster: Watson och hans lika ordinära efterföljare fungerar som identifikationsobjekt för läsaren, och deras begränsade perspektiv utgör en förutsättning för finalens överraskningseffekt.[50] Samtidigt framträder en latent spänning - Watson måste framstå som pålitlig såväl i sin moral som i egenskap av Holmes' arkivarie, men riskerar också, med Viktor Sjklovskijs ord, att uppfattas som "den evige fårskallen".[51] Trenter utnyttjar mönstret med jämförbara konsekvenser för Friberg. Huvudpersonen som tilldelats generöst utrymme för sina värderingar och avsevärd vikt som exemplariskt mönster, ter sig hjälplös och ibland naiv då han nu ställs inför brottet. Hjältens ideologiska funktion tenderar att undergrävas av det narrativa greppet. Mot hans uppgift som framtidsmodell ställs bilden av den lilla människan vars goda vilja och engagemang är otillräckliga redskap i det spel som pågår.

Kännetecknande för Trenters 40-talsromaner är att också poliserna får en ambivalent framtoning. Visserligen löser de gåtorna, men utan att tilldelas den betryggande samhälleliga auktoritet som annars blivit vanlig i den moderna polisromanen och i den svenska 50-talsdeckaren av Maria Langs eller Vic Sunesons fason. I Farlig fåfänga känner Friberg en uppenbar dragning till mordoffrets syster Lena men plågas av misstankar om 
hennes skuld. $\AA$ andra sidan biträder han i utredningen kommissarie Lind, som snarast ter sig som en mönstergill representant för krigstidens slogan "En svensk tiger!". Lind förkroppsligar en kompetent men opersonlig myndighet, imponerande i sina till synes outtömliga resurser, men också aningen hotfull i sin svårtillgänglighet. Friberg får ofta nöja sig med halvkvädna besked och känner "obehag" inför hans planer (FF, s. 212). Bilden av en polismakt som "vet allt som sker" återkommer också i några följande romaner som en lätt ironisk kommentar till övervakningssamhället (LL, s. 85).

Redan i seriens andra del, I dag röd, har Lind efterträtts av Vesper Johnson, vars neurotiskt oberäkneliga karaktär och pedantiska snobbighet iakttas av den ofta förundrade Friberg. Johnson, som omväxlande berömmer och hudflänger sin ambitiöse adept, ser ut som en bäver och har en knäande gångart à la Groucho Marx. Trots sina stunder av genialitet är han definitivt alltför excentrisk och osvensk för att kunna passera som en av de nationella mytfigurer som enligt Dennis Porter bär upp genrens bekräftande ideologi. Däremot utvecklas relationen Friberg och Johnson emellan till en stabiliserande faktor mitt i brottshistoriens kaos. I synnerhet scenerna kring deras gemensamma upplevelse av bordets håvor ger antydningar om att rättskänsla vilar på manlig vänskap och kan sägas understryka ett könsideologiskt mönster som är tydligt också i andra avseenden.

Spelet mellan Vesper Johnson och Friberg tillför romanerna färgstyrka, situationskomik och rapp replikföring. I genreperspektivet framstår paret som en halvt parodisk upplaga av konstellationen Watson-Holmes, men till skillnad från Watson blir Friberg aldrig överskuggad av sin parhäst.[52] Vesper Johnson är förvisso föremål för hans fascination, men samtidigt ger Trenter Friberg ett stort självständigt spelrum i undersökningen och framförallt får texterna mycket av sin energi från dennes intensiva, ofta starkt emotionella deltagande i brottshistorierna och i de sociala världar han möter. Friberg ställs gärna i definitiv närhet av händelsernas centrum och överbryggar den opersonliga, intellektualiserade distans till "fallet" som är så framträdande i många pusseldeckare. Han känner Paul Groth och hans familj liksom han också skall visa sig vara bekant med de berörda i Tragiskt telegram och i Eld i håg. Han får vädra sina personliga intryck av de karaktärer han möter och avslöjar i ord och gärning även starka sympatier.

Friberg ter sig som ett exempel på hur fokus i kriminalromanen vid denna tid börjat förskjutas från de briljanta detektiverna till vardagligare, ofta psykologiskt mera nyanserade, karaktärer och till deras upplevelse av mötet med brottet. Som en tidig föregångare kan man då uppfatta den mänskligt bristfällige detektiv, som Stieg Trenter lär ha tagit sitt namn efter och som uppträder i E.C. Bentleys Trents sista fall från 1913, en konstnär och journalist som vid sidan av sin, felaktiga, analys av fallet också hinner med att förälska sig i den mördades nyblivna änka.[53] John Dickson Carrs Svart sabbat, ännu en av Trenters favoriter, har som huvudperson en bokförläggare som oroas över hustruns eventuella delaktighet i ett mord. Likheterna med Farlig fåfänga är tydliga. Populär under krigsåren i Sverige var också pseudonymen Jonathan Stagge, vars romaner berättas av en doktor Westlake, änkling med minderårig dotter, och liksom Friberg involverad i olika brottsfall där han flera gånger ser sig grundligt bedragen. Till detta kan dessutom läggas en rad filmer av Alfred Hitchcock där mer eller mindre vardagliga hjältar och hjältinnor finner sig indragna i härvor av spionage och kriminalitet - De trettionio stegen, En dam försvinner, Utrikeskorrespondenten, Skuggan av ett tvivel.

Julian Symons menar att föreställningen om "Den Store Detektiven" inte kunde överleva andra världskrigets erfarenheter av att "förnuftets värld" hade gått under och ersatts av maktens och styrkans.[54] Symons förkortar visserligen en långdragen process till krigets avgörande skede, men pekar på en väsentlig förändring i det mentala klimat som utgjorde en förutsättning för bl.a. Trenter. Fribergs förvirring och hjälplöshet bör delvis förstås mot bakgrund av krigstidens ständiga oro.

Ytterligare en förklaring till utvecklingen är att den traditionella pusseldeckaren helt enkelt inte kunde uttömma kriminaliteten som litterärt motiv eller intresseväckande socialt och psykologiskt fenomen. Mönstret var visserligen både etablerat och populärt, men dess 
snävhet uppmanade samtidigt till variation. Lockelsen att knyta romanernas värld tätare till publikens låg också mer eller mindre latent inom en genre som ännu hos Conan Doyle hade förenat den intellektuella gåtan med en bred samhällsskildring och med det vardagsmänskliga perspektiv Watson erbjöd. Ryktbar i sammanhanget är Raymond Chandlers essä The Simple Art of Murder från 1944, där han hånade pusseldeckaren för dess bristande realism, förkärlek för överklassmiljöer och "mord parfymerade med magnoliablom", och för dess okunskap om elementära polisiära och juridiska rutiner.[55] Även om Chandler representerar ett radikalt brott med den förhärskande traditionen, kan man också se hans kritik som symptomatisk för en bredare strävan bort från pusseldeckarens trånga värld.

\section{Skulden}

Finalen och avslöjandet sker hos Trenter antingen, som i Farlig fåfänga, genom det teatrala greppet att samla samtliga berörda till en sista genomgång då mördaren namnges, eller, som i flera andra romaner, via en polisjakt där ingripandet "i sista sekunden" räddar ännu ett tilltänkt offer. Hela sammanhanget blir nu klarlagt; lösningen visar sig ofta ha funnits framför läsarens ögon men bedrägligt infogad i mängden av empiriska iakttagelser, en detalj som uppslukats av strömmen av dramatik. Pusseldeckaren har av hävd en dragning mot illusionstricket. Redan Poe ställde läsaren inför det till synes omöjliga, då han placerade ett antal mordoffer i ett hermetiskt slutet rum, låst inifrån och till vilket ingen gärningsman tycktes ha kunnat skaffa sig tillträde. John Dickson Carr framstår som den kanske mest avancerade illusionisten i sin generation och Trenter visar en tydlig strävan att åstadkomma motsvarande överraskningseffekter.

Hos flera av kriminalromanens teoretiker återkommer tanken att upplösningen ger en särskild ideologisk skärpa åt genren. Dennis Porter skriver om pusseldeckaren: "Against the background of a civilized order founded on the socio-economic relations of English rural life, crime in detective fiction appears as an aberration; it is the exception which proves the rule of moral order".[56] John G. Cawelti formulerar sig likartat: "The detective proves the social order is not responsible for the crime because it was an act of a particular individual with his own private motives".[57] En tredje version, signerad Ernest Mandel, sammanfattar genremönstret: "...irrationaliteten som stör rationaliteten, rationaliteten som återställs efter irrationella omvälvningar; det är det som kriminalromanen handlar om".[58]

Richard Alewyn framträder med en delvis avvikande mening. Det är "detektivens uppgift att återupprätta tron på den hotade kausaliteten", skriver visserligen Alewyn, men han betonar också att "[p]usslet är liknelsen om restaurationen av en sönderstyckad värld, detektivromanen är liknelsen om förstörandet av en intakt värld".[59] De hemligheter som kommit i öppen dager under undersökningens gång - "blottläggandet av kontrasten mellan det idylliska skenet och den mindre uppbyggliga verkligheten" - har en gång för alla raserat föreställningarna om en normalitet och gärningsmannen spelar framförallt rollen som "syndabock" för den kollektiva skuld som uppenbarats.[60]

Alewyn kan i och för sig kritiseras för motsvarande ensidighet som Cawelti, Porter eller Mandel, men han belyser en potentiell tvetydighet i genremönstret, en spänning som i sin tur kan leda till skilda läsarter. Även en författare som Agatha Christie, ofta beskylld för att underblåsa idylliska föreställningar om engelskt lantliv, kan läsas med tonvikt på de oroande påminnelser om mänskligt dubbelspel - "Varenda en av er döljer någonting", upprepar Poirot i Dolken från Tunis - som aldrig helt utplånas av romanernas okomplicerade tilltro till samhällssystemet, inte heller av deras försök att dämpa våldshandlingens brutalitet och balansera denna mot inslag av komedi och romantik.[61]

Trenter följer pusseldeckarens normer i så måtto att mördarens identitet, handlingssätt och motiv i varje roman kan fastslås bortom allt tvivel. Brottet individualiseras och hänförs, likaledes i konventionell ordning, till sådana privata mänskliga drivkrafter, girighet och svartsjuka framförallt, som kan sägas vara evigt återkommande och utan relation till specifika samhällssystem.[62] Men mot denna ideologiskt bekräftande läsart kan samtidigt 
ställas en annan, där mordet och undersökningen istället uppenbarar mörka sidor hos en samtid, som kan stimulera till omoral, egoism och ekonomisk hänsynslöshet. Skulden tillhör då ett moraliskt klimat snarare än den enskilde gärningsmannen, romanernas värld ter sig, i enlighet med Alewyn, snarare sönderstyckad än återställd.

Inga av romanernas brottslingar beskrivs som onda människor - den enda som uttalat förknippas med ondska är istället ett av offren i Tragiskt telegram (TT, s. 211). Flera av mördarna förses däremot med karaktärsdrag som är ägnade att vinna läsarnas sympati. Deras handlingar är heller inte som så ofta i de anglosaxiska pusseldeckarna resultatet av någon raffinerad planering; snarare har de agerat impulsartat, i ett avgörande ögonblick gett vika för defekter som inte enbart kan hänföras till personlighet utan också till en mentalitet i samtiden. Strävan att nyansera bilden av gärningsmannens djävulska förslagenhet kommer samtidigt att konkurrera med ambitionen att presentera ett svårforcerat problem. Romanerna kompromissar mellan nedärvda estetiska krav och en syn på kriminalitet som uppenbart skiljer sig från föregångarnas. Trenters lösning är att göra brottslingarna till ett slags improvisationens genier, som när de moraliska spärrarna väl släpper griper tillfället och lyckas utnyttja det till att skapa maximal förvirring. Mördarna i Farlig fåfänga, Lysande landning, Tragiskt telegram, Träff i helfigur och Eld i håg besitter alla denna förbluffande talang.

Farlig fåfänga är representativ för Trenters 40-talsproduktion i det att den innehåller både den sammanflätning av familj och affärsvärld och det typgalleri som sedan skall varieras i de följande sex romanerna. Ur en aspekt närmar sig Trenter den borgerliga roman som vid denna tid fortfarande frodas och har en stor publik. Texterna kan läsas som ett spel mellan den frihet och framtidstro Friberg företräder som representant för en ny medelklass, och de borgerliga familjer vars medlemmar istället både binder och utnyttjar varandra i elakartade mönster. Familjerna Groth i Farlig fåfänga, Leffler i I dag röd, Orten i Eld i håg och den släkt paret Seghers tillhör i Tragiskt telegram ter sig alla utomordentligt avskräckande, syskontrion Haag i Lek lilla Louise är aningen mindre disharmonisk. Lysande landning och Träff $i$ helfigur fokuserar däremot snarare spänningarna inom det moderna äktenskapets tvåsamhet.

Den första berättelsen om Friberg kan betecknas som den ljusaste i så måtto att Trenter helt följer den konventionella moral som pusseldeckaren ofta anpassar sig till - brottslingen är en figur som texten tidigt riktar starka antipatier emot, dygden och tålamodet får sin belöning, en hotande skilsmässa blir avvärjd, och flera karaktärer får demonstrera sin renhårighet.[63] Detta facit uppnås emellertid inte utan att Trenter provocerat genrenormerna. Då Lena Groth, som ständigt fått åsidosätta sina behov till förmån för brodern Paul, ställs i centrum för misstankarna om mordet tycks romanen öppna sig för en mer realistisk läsart som ända fram till upplösningen underhålls av Fribergs vacklande inställning till den unga kvinnan. Det är också först sedan kommissarie Lind med en falsk lösning pekat ut just Lena och därvid gjort Friberg "illamående" (FF, s. 241), som Trenter istället tillgriper den önskeuppfyllelse som friar den unga kvinnan. Det arv hon nu kan förvänta sig efter brodern förvandlar henne från "askunge" till "prinsessa" heter det på sista sidan, möjligen med viss ironi mot sagomönstret (FF, s. 254).

I romanerna återkommer ett antal typer, som tillsammans ger ett tydligt könsideologiskt mönster åt Trenters värld av borgerlighet och medelklass. Frågan om brottet och skulden förbinds med sedeskildringens strävan att peka ut samtidens moraliska brister men också dess föredömen. Lena Groth är då den första i en serie av goda kvinnokaraktärer, som genom att uppfylla den traditionella kvinnorollens krav ställer sig utanför det moderna samhällets frestelser. Lena har inte enbart haft en otacksam pigroll i hemmet, utan visar dessutom sanna moderskänslor då hon tar hand om och föresätter sig att adoptera barnhusbarnet Marianne, en flicka som i sin tur blivit offer för kvinnlig ansvarslöshet. Den biologiska modern sägs föredra "restauranger och galanta herrar framför hemmet och dottern" (FF, s. 95). Helen Lessler i I dag röd har vandrat en törnestig i äktenskapet med den karaktärslöse Gilbert, men nu gett sig på en utbildning på vävskola, en traditionellt kvinnlig sektor. När Friberg ser henne vid vävstolen, träffas hennes ansikte av en 
infallande solstråle och lyser "som förklarat [---] Lockarna som stack fram under scarfen flammade som eldslågor i motljuset" (IDR, s. 122). Den Helen som här förses med strålglans från himlen får i slutänden liksom Lena Groth sin belöning i form av arv. Madeleine Lenke i Lysande landning är ännu en av dessa prövade kvinnor, ett offer för den "fysiska attraktionen" hos den bildsköne Alex, men nu snarare livsklok än besviken ( LL, s. 167). Monica Iverson i Träff $i$ helfigur saknar helt makens fåfänga och gör inte ens anspråk på den roman hon själv har skrivit. Mera komplicerad är till sist Aina Regnell i Lek lilla Louise, ett exempel på att godheten och tålamodet ändå kan svikta. Hon har under en lång period varit älskarinna i lönndom åt den rike Douglas Haag och blir mördare snarast av misstag då hon riskerar att förlora honom till en betydligt yngre kvinna.

Mot denna grupp står ett antal klichémässiga femmes fatales, som i olika grad bidrar till omoralens smitta. Minst uppseendeväckande är den Mona Lisa-liknande Elisabeth Montell i den första romanen - hon övervinner frestelsen att rymma med Paul Groth och återvänder till sin betydligt äldre make, en klok och omtänksam läkare. Mary Lessler, mördare i I dag röd, beväpnas med ögon som hämtade ur den kvinnliga demonologin. "Jag vet inte hur länge jag såg in i dem. Det föreföll mig vara en evighet, och jag var oförmögen att slita mig loss ifrån dem. Jag har aldrig erfarit något liknande", berättar Friberg (IDR, s. 77). Lyxbegäret är drivkraft för Mary liksom för den kattliknande Lilly Stenmark, vars flirtighet orsakar mord i Lysande landning. Hennes blick är istället isig som "vintrigt havsvatten" (LL, s. 131). Närmast vampyrartad är Velma Orten i Eld $i$ håg, som varit gift med familjeöverhuvudet Gilbert, älskarinna till dennes brorson Robert, förlett brorsdottern till traumatiska sexuella äventyr och nu anstränger sig hårt för att förföra Friberg. Dessa farliga damer uppträder i romanerna med en frekvens som delvis kan förklaras med typens popularitet inom dåtida film noir, men samtidigt fogar sig Trenter till en framförallt manlig tradition där den erotiskt tilltagsna kvinnan använts som tecken på allmänt sedefördärv.[64]

Äldre kvinnor som övertagit rollen av familjeöverhuvud får genomgående skylta med sina brister. Redan i familjen Groths bostad möter vi en änka, vars svaghet understryks av att hon sitter i rullstol, och som uppenbart förstört barnens ömsesidiga relation genom att favorisera sonen Paul. I Tragiskt telegram har två änkor fått ärva var sitt storföretag men är upptagna av intriger mot varandra och av de erotiska vidlyftigheter som här sägs höra till kvinnans "farliga år" (TT, s. 178). Monica Iversons roman i Träff i helfigur beskrivs som en uppgörelse med "den moderskärlek som kräver allt och ger så lite, som suger ut och förkväver" (TIH, s. 278). Modern är även i det här fallet änka. Också våldsverkaren i Farlig fåfänga, den medelålders konsthandlaren och änkan Maud Björkman kan uppfattas som en ond moder, en kvinna som är närmast karikatyrartat präglad av just fåfänga - "född von Gestern" - och som väljer att beröva den unge Paul Groth synen snarare än att förlora honom till sin konkurrent. Pauls reaktioner mot henne jämförs också vid ett tillfälle med ett "genstörtigt barns" (FF, s. 37).

Paul Groth är den förste i ett galleri av svaga män i Fribergs egen ålder och som på skilda sätt förkroppsligar laster som leder till undergång. Jämförelsen med huvudpersonen underlättas av att t.ex. den sympatiske men bortskämde och lättjefulle Curt Seghers i Tragiskt telegram liksom Groth till och med är skolkamrat med Friberg. Robert Orten i Eld $i$ håg, begåvad men missnöjd med sin yrkesposition, är bekant med honom sedan tidigare. Både han och Seghers blir mördare och så också Gösta Stenmark i Lysande landning, framgångsrik industriman men offer för en svartsjuka som driver honom till brott. Föremålet för hans hat, Alex Lenke, är i sin tur "feminint kokett", uppenbart narcissistiskt belåten med sitt "snarfagra filmhjälteutseende" (LL, s. 32). Författaren Alf Iverson i Träff i helfigur arrangerar sitt självmord i avsikt att hämnas på hustrun och hennes f.d. älskare. Han är en variant på Groth, en neurotiskt egofixerad konstnärsnatur som kränkts i sitt innersta av att hustrun Monica i själva verket har skrivit den succéroman som utkommit i hans eget namn. Iversen representerar dessutom den anspråksfulla modernism som gärna utsätts för Trenters spe. Gilbert Lessler, ett av offren i I dag röd, framställs som en odugling i alla avseenden, likgiltig för sin trofasta hustru, inriktad på att leva på faderns pengar. Storbyggmästaren Douglas Haag i Lek lilla Louise har kunnat vidareutveckla ett ärvt imperium men samtidigt sexuellt utnyttjat en kvinna dithän att hon mördar. De 
äktenskap Friberg får inblick i via dessa och andra figurer är så gott som undantagslöst olyckliga och genomgående barnlösa, något som ytterligare stärker intrycket av aktörernas sterilitet och självupptagenhet.

Men i texterna kan också spåras vad som fattas det nya samhället. I Farlig fåfänga framstår den jovialiske konsthandlaren Bergsten som ett exempel på välviljan och rättrådigheten hos en äldre manlig generation. Det kontrakt han erbjudit Groth, "pojken", beskrivs som "en god affär" för båda parter, ett avtal i linje med dåtida svensk samförståndsanda (FF, s. 141). Bergsten är samtidigt ett undantag. De fadersgestalter som i övrigt förekommer i romanerna och ges en positiv värdering är antingen redan döda eller faller nu offer för våldet. Såväl Lena Groth som Monica Iverson, två av de goda kvinnorna, hårt prövade av männen i sin närhet, ges tillfälle att betona sina ljusa minnen efter fäderna. Sven Lessler i $I$ dag röd är en kompetent företagsledare som dessutom fungerat som välvillig patriark gentemot syskon och barn utan motsvarande energi eller duglighet. Han väljer att ta sitt liv sedan han vådaskjutit sonen. Gilbert Orten, mordoffer i Eld i håg, har spelat en liknande roll gentemot sina syskonbarn. Douglas Haags bortgångne far blir omtalad som "en hedersman" (LLL, s. 101). Det är symptomatiskt att gripandet av mördaren i Träff $i$ helfigur sker mot bakgrund av folkmassornas hyllning till Gustav V vid hans 90-årsdag 1948. Mot den åldrige kungen som symbol för traditionen och krigsårens nationella enighet ställs den kvinna, Jenny Iverson, som mördat svägerskan Monica för att kunna förverkliga sina drömmar om en modebutik och som på så sätt får representera nutidens egoism, girighet och flärd.

Det förflutna ter sig oskyldigt hos Trenter. Brottet och skulden uppstår i nuet och har, i motsats till en rad andra kriminalförfattare, inte sitt ursprung i historiens fördolda. Hos Simenon, Chandler och hos Trenters 50-talskonkurrent Maria Lang hemsöks nutiden av det förgångna, bakom fasaderna gror sedan decennier en moralisk röta. Hos Trenter däremot står betecknande nog ett stall från karolinertiden i Tragiskt telegram likt "en tapper gammal drabant" som "med förtvivlans mod håller stånd mot den anstormande fienden" (TT, s. 9), här den moderna arkitektur som brutalt visar sin vanvördnad inför det förflutna. En författare som annars är befriad från 30- och 40-talets inskränkta nationalism frammanar vid enstaka tillfällen den forna svenskhetens dygder i dess kamp mot samtiden.

Men bilden av den gamle drabanten och hans "förtvivlans mod" anger också styrkeförhållandet. Historien lever hos Trenter framförallt som ett sentiment, ett ögonblick av nostalgi där en förlorad stabilitet återkallas. Fäderna är döda eller dömda att försvinna likt den 90-årige monarken, slottet brinner i Eld i håg och i Lek lilla Louise ligger ett mordoffer begravt på Fersenska terrassen. Vad som återstår är en hektisk nutid med alla dess möjligheter och dess övermäktiga frestelser.

En sista oförlöst spänning framträder i texterna och medverkar till att ge Trenters 40talsromaner en specifik karaktär. Romanerna skildrar ett samhälle utan självklar auktoritet, vare sig i den gamla patriarkala ordningens fadersfigurer eller via de kriminalromanens traditionella hjälteroller, som här axlas av den närmast hjälplöse Harry Friberg och den neurotiske Vesper Johnson. Inom ramen för det svenska folkhemmet ifrågasätter de på så sätt vad Zygmunt Bauman har kallat det "nationalistiska löftet om en hemlik trygghet", de bearbetar osäkerheten hos framförallt den medelklass som upplevt krigsåren och nu levde i ett samhälle på väg att omdanas.[65] Mot en läsart som stimulerar oron inför samtiden står å andra sidan en, som i den maskulina vänskapen mellan Friberg och Johnson finner en betryggande ersättning för deras individuella brister, eller som kan ta fasta på romanernas optimism och framstegstro, deras traditionella medelklassvärden och de måttlighets- och skötsamhetsideal som var starkt förankrade i folkhemmets gemenskap.

(C) Ulf Carlsson

\section{Litteratur}


Följande upplagor av Stieg Trenters romaner har använts:

Som man ropar (1944), Bonniers 1948

Farlig fåfänga (1944), Bonniers, 1949

I dag röd (1945), Bonniers, 1983

Lysande landning (1946), Bonniers, 1957

Tragiskt telegram (1947), Bonniers, 1985

Träff i helfigur (1948), Bonniers, 1956

Eld i håg (1949), Bonniers, 1960

Lek lilla Louise (1950), Bonniers, 1979

Alewyn, Richard, "Detektivromanens anatomi", i Brott, kärlek, äventyr. Texter om populärlitteratur, red. Dag Hedman, Studentlitteratur 1995

Ambjörnsson, Ronny, Den skötsamme arbetaren. Idéer och ideal i ett norrländskt sågverkssamhälle, Carlsson 1988

Asplund, Johan "Stieg Trenters gåtor", i En bok om Stieg Trenter

Barthes, Roland, "Roland Barthes on the Reality Effect in Descriptions", i Realism, red.

Lilian R. Furst, Longman 1995

Bauman, Zygmunt, Vi vantrivs i det postmoderna, Daidalos 1998.

Billing, Peter och Stigendal, Mikael, Hegemonins decennier; lärdomar från Malmö om den svenska modellen, Möllevångens samhällsanalys 1994

Cawelti, John G., Adventure, Mystery, and Romance. Formula Stories as Art and Popular

Culture, Chicago University Press 1976

Chandler, Raymond, Mordets enkla konst, Janus 1984

Daun, Åke, Svensk mentalitet. Ett jämförande perspektiv, Rabén \& Sjögren 1989

Eagleton, Terry, Criticism and Ideology. A Study In Marxist Literary Theory, Verso 1998

Eagleton, Terry, Ideology. An Introduction, Verso 1991

Eagleton, Terry, "Form and Ideology in the Anglo-Irish Novel", Heathcliff and the Great

Hunger. Studies in Irish Culture, Verso 1996

Easthope, Antony, Literary into Cultural Studies, Routledge 1991

Elgström, Jörgen och Runnquist, Åke, Svensk mordbok. Den svenska detektivromanens historia 1900-1950, Sällskapet Bokvännerna u.å.

Freeman, R. Austin, "Detektivromanen som skön konst", i Meningar om mord. 15 uppsatser om deckare, deckarförfattare och deckarhjältar, red. Jan Broberg, Bo Cavefors bokförlag 1968

Frykman, Jonas, Dansbaneeländet. Ungdomen, populärkulturen och opinionen, Natur och Kultur 1988

Frykman, Jonas och Löfgren, Orvar, Den kultiverade människan. Liber 1979

Frykman, Jonas och Löfgren, Orvar, "På väg - bilder av kultur och klass", i Modärna tider. Vision och vardag i folkhemmet, red. Frykman och Löfgren, Liber 1985

Hall, Stuart, "Gramsci's relevance for the study of race and ethnicity", i Stuart Hall.

Critical Dialogues in Cultural Studies, red. David Morley och Kuang-Hsing Chen,

Routledge 1996

Hirdman, Yvonne, Att lägga livet till rätta. Studier i svensk folkhemspolitik, Allmänna

förlaget 1989

Isaksson, Anders, Per Albin. III. Partiledaren IV. Landsfadern, Wahlström \& Widstrand 2002

Johansson, Alf W., "Inledning. svensk nationalism och identitet efter andra världskriget", i Vad är Sverige? Röster om svensk nationell identitet, red. Alf W. Johansson, Prisma 2001

Knight, Stephen, Form and Ideology in Crime Fiction, MacMillan 1980

Larrain, Jorge, "Stuart Hall and the marxist concept of ideology", i Stuart Hall. Critical

Dialogues in Cultural Studies, red. David Morley och Kuang-Hsing Chen, Routledge 1996

Löfgren, Orvar, "Nationella arenor", i Ehn / Frykman / Löfgren, Försvenskningen av

Sverige. Det nationellas förvandlingar, Natur och Kultur 1993

Macherey, Pierre, A Theory of Literary Production, Routledge \& Kegan Paul 1978

Mandel, Ernest, Förtjusande mord, Alfabeta 1985

Munt, Sally R., Murder by the Book? Feminism and the Crime Novel, Routledge 1994

Porter, Dennis, The Pursuit of Crime. Art and Ideology in Detective Fiction, Yale 
University Press 1981

Qvist, Per Olov, Jorden är vår arvedel: landsbygden i svensk spelfilm 1940-1959,

Filmhäftet 1986

Qvist, Per Olov, Folkhemmets bilder: modernisering, motstånd och mentalitet i den svenska 30-talsfilmen, Arkiv 1995

Sjklovskij, Viktor, "Kriminalberättelsen hos Conan Doyle", i Brott, kärlek, äventyr. Texter om populärlitteratur, red. Dag Hedman, Studentlitteratur 1995

Stigendal, Mikael, "Hegemoni - sfärernas och gränsernas överskridande", Zenit 109/110 1989

Symons, Julian, Lilla mordboken. Från detektivhistoria till kriminalroman - en historik, Berghs förlag 1979

Williams, Raymond, Marx och kulturen. En diskussion kring marxistisk kultur- och litteraturteori, Bonniers 1980

[1] Simenon översattes med tre romaner om kommissarie Maigret redan 1934, men därefter inte förrän 1950. Chandler översattes först 1947.

[2] Ernest Mandel, Förtjusande mord, Alfabeta 1985, s.25, 36.

[3] John G. Cawelti, Adventure, Mystery and Romance. Formula Stories as Art and

Popular Culture, Chicago University Press 1976, s.13, 30, 105.

[4] Stephen Knight, Form and Ideology in Crime Fiction, MacMillan 1980, s. 2, 5, 71, 107, 121.

[5] Knight s. 3.

[6] Mandel s. 39.

[7] Cawelti s.105; R. Austin Freeman, "Detektivromanen som skön konst", i Meningar om mord. 15 uppsatser om deckare, deckarförfattare och deckarhjältar, red. Jan Broberg, Bo

Cavefors bokförlag 1968, s. 41.

[8] Dennis Porter, The pursuit of Crime. Art and Ideology in Detective Fiction, Yale

University Press1981, s. 3, 108, $219 \mathrm{f}$.

[9] Porter s. 125ff, 156f, 173, 197, 216.

[10] Porter s.160.

[11] Pierre Macherey, A Theory of Literary Production, Routledge \& Kegan Paul 1978, s.

131, 133.

[12] Terry Eagleton, Criticism and Ideology. A Study In Marxist Literary Theory, Verso

1998, s. 69, 81, 84.

[13] Eagleton, Criticism, s. 98, 64, 96.

[14] Eagleton, Criticism, s. 37.

[15] Terry Eagleton, "Form and Ideology in the Anglo-Irish Novel", Heathcliff and the

Great Hunger. Studies in Irish Culture, Verso 1996, s. 168, 178, 193, 200, 204.

[16] Terry Eagleton, Ideology. An Introduction, Verso 1991, s. 7ff.

[17] Jorge Larrain, "Stuart Hall and the marxist concept of ideology", i Stuart Hall. Critical

Dialogues in Cultural Studies, red. David Morley och Kuang-Hsing Chen, Routledge 1996,

s. 53. Se också Terry Eagleton, Ideology, s. 29.

[18] Antony Easthope, Literary into Cultural Studies, Routledge 1991, s. 99.

[19] Orvar Löfgren, "Nationella arenor", i Ehn / Frykman / Löfgren, Försvenskningen av

Sverige. Det nationellas förvandlingar, Natur och Kultur 1993, s. 57 f.

[20] Yvonne Hirdman, Att lägga livet till rätta. Studier i svensk folkhemspolitik, Allmänna

förlaget 1989, i synnerhet s. 216-239. Se också Jonas Frykman och Orvar Löfgren, "På väg

- bilder av kultur och klass", i Modärna tider. Vision och vardag i folkhemmet, red.

Frykman och Löfgren, Liber 1985.

[21] Eagleton, Ideology, s. 116.

[22] Mikael Stigendal, "Hegemoni - sfärernas och gränsernas överskridande", Zenit 109/110 1989.

[23] Peter Billing och Mikael Stigendal, Hegemonins decennier; lärdomar från Malmö om den svenska modellen, Möllevångens samhällsanalys 1994.

[24] Se Stigendal, "Hegemoni - sfärernas och gränsernas överskridande" och Stuart Hall, "Gramsci's relevance for the study of race and ethnicity", i Stuart Hall. Critical Dialogues in Cultural Studies, red. David Morley och Kuang-Hsing Chen, Routledge 1996, s. 424 ff. 
Hall betonar bl.a. att "hegemoni" i Gramscis ursprungliga tillämpning avser endast mycket specifika historiska faser. Av andra uttolkare har begreppet däremot använts mera frikostigt, med avseende på stabila maktsituationer överhuvudtaget.

[25] Raymond Williams, Marx och kulturen. En diskussion kring marxistisk kultur- och litteraturteori, Bonniers 1980 s. 92 ff. Se också Hall s. 433. Williams betonar å ena sidan att hegemoni upprätthålls genom en ständigt pågående förnyelse och modifiering, där dominerande idéer måste möta, bearbeta och ibland införliva alternativa eller oppositionella former. Inom ramen för hegemonin finns på så sätt utrymme både för konflikt och variation och man behöver inte tänka sig en fullständig ideologisk överensstämmelse mellan de olika skikt som hegemonin vilar på. Att man förutsätter att ideologier utövar ett tryck på sin samtid och dess texter medför då heller inte att texterna skall ses som alltigenom ideologiskt bestämda. $\AA$ andra sidan skriver Williams att hegemonibegreppet uppfattar förhållandena mellan dominans och underlydnad som "genomsyrade av levandets hela process ( ... ) till ett sådant djup att trycket av och gränserna för vad som i sista hand kan ses som specifika ekonomiska, politiska och kulturella system för de flesta av oss verkar vara trycket av och gränser för enkla erfarenheter och sunt förnuft". Mot de spänningar och den mångfald som hegemonin förutsätts innehålla står här istället en massiv och uniform påverkan. I linje med denna tolkning har också populärkulturella texter reducerats till enkla uttryck för den "dominerande ideologin" eller "hegemonin".

[26] Hall s. 437.

[27] Frykman och Löfgren, "På väg - bilder av kultur och klass", s. 137.

[28] Anders Isaksson, Per Albin. III. Partiledaren IV. Landsfadern, Wahlström \& Widstrand 2002.

[29] Jonas Frykman, Dansbaneeländet. Ungdomen, populärkulturen och opinionen, Natur och Kultur 1988.

[30] Per Olov Qvist, Jorden är vår arvedel: landsbygden i svensk spelfilm 1940-1959,

Filmhäftet 1986.

[31] Cawelti s. 82.

[32] Per Olov Qvist, Folkhemmets bilder: modernisering, motstånd och mentalitet i den svenska 30-talsfilmen, Arkiv 1995, s. 411.

[33] Jörgen Elgström och Åke Runnquist, Svensk mordbok. Den svenska detektivromanens historia 1900-1950, Sällskapet Bokvännerna u.å., s. 124.

[34] Jonas Frykman och Orvar Löfgren, Den kultiverade människan. Liber 1979.

[35] Frykman och Löfgren, "På väg", s.75-78.

[36] Åke Daun, Svensk mentalitet. Ett jämförande perspektiv, Rabén \& Sjögren 1989, s. $121 \mathrm{ff}$.

[37] Hirdman, s. 110.

[38] Alf W. Johansson, "Inledning. svensk nationalism och identitet efter andra världskriget", i Vad är Sverige? Röster om svensk nationell identitet, red. Alf W. Johansson, Prisma 2001, s. 11.

[39] Ronny Ambjörnsson, Den skötsamme arbetaren. Idéer och ideal i ett norrländskt sågverkssamhälle, Carlsson 1988.

[40] Eagleton, Ideology, s. 56-61.

[41] Ingemar Johansson, StorStockholms bebyggelsehistoria. Markpolitik, planering och byggande under sju sekler, Gidlunds 1987, s. 483.

[42] Qvist, Jorden är vår arvedel, s..207ff.

[43] Jan Broberg "En bok om Stieg Trenter", i En bok om Stieg Trenter, Jury u.å. s. 8. Vad gäller John Dickson Carr, se bl.a. Tusen-och-en-nattmysteriet ( The Arabian Night Murders, 1936 ), Skoglunds 1936, och Svart sabbat ( The Burning Court, 1937 ), Bonniers 1939.

[44] Stieg Trenter, Som man ropar (1944), Bonniers 1948, s. 40.

[45] Trenter åstadkommer gärna en hel uppsättning mystifikationer redan i sina inledningar. Johan Asplund har lyft fram ett tacksamt exempel, öppningskapitlet i Lek lilla Louise, där det bisarra gränsar till absurd komik. Friberg och hans ornitologiskt intresserade fotoassistent klättrar upp i ett träd, fastnar först i en ålsax, finner därefter en uppsättning dockmöbler i ett fågelbo, och till sist en giljotin i en närbelägen lada. Se Asplund, "Stieg Trenters gåtor", i En bok om Stieg Trenter, s. 85. Farlig fåfänga opererar 
med likartade grepp: mordet föregås av en oförklarligt sönderriven tavla, en cypress flyttar sig i kvällsmörkret, en okänd kvinnogestalt slänger hånskrattande en brinnande tändsticksask mot Friberg.

[46] Richard Alewyn, "Detektivromanens anatomi", i Brott, kärlek, äventyr. Texter om populärlitteratur, red. Dag Hedman, Studentlitteratur 1995, s. 179.

[47] Roland Barthes, "Roland Barthes on the Reality Effect in Descriptions", i Realism, red. Lilian R. Furst, Longman 1995.

[48] Porter, s. 43.

[49] Alewyn, s. 163.

[50] Cawelti, s. 83f; Porter, s. 27.

[51] Viktor Sjklovskij, "Kriminalberättelsen hos Conan Doyle", i Brott, kärlek, äventyr.

Texter om populärlitteratur, red. Dag Hedman, Studentlitteratur 1995, s. 195.

[52] Holmes-Watson kopierades i sådan utsträckning att man redan på 30-talet kan finna ironiska varianter. Jan Broberg betonar just likheterna mellan Friberg-Johnson och det par som uppträder hos Rex Stout, översatt till svenska med fem titlar redan 1940. Hos Stout underhåller den pompöse Nero Wolfe en relation till sin assistent Archie Goodwin av liknande slag som hos Trenter. Se Broberg, "En bok om Stieg Trenter", s. 9.

[53] Arne Holmström, "Så här började det-", i En bok om Stieg Trenter, s. 26.

[54] Julian Symons, Lilla mordboken. Från detektivhistoria till kriminalroman - en historik, Berghs förlag 1979, s. 176. Sally R. Munt framhåller istället de kvinnliga deckarförfattarnas betydelse för ett växande psykologiskt intresse inom genren. Se Munt, Murder by the Book? Feminism and the crime Novel, Routledge 1994,s. 14.

[55] Raymond Chandler, Mordets enkla konst ( The Simple Art of Murder ), Janus 1984, s. $14,39$.

[56] Porter s. 196.

[57] Cawelti s. 96.

[58] Mandel s. 53.

[59] Alewyn s. 181, 176.

[60] Alewyn s. $171 \mathrm{ff}$. Se också Munt, s. $8 \mathrm{f}$.

[61] Agatha Christie, Dolken från Tunis (The Murder of Roger Ackroyd, 1926), B.

Wahlströms Bokförlag 1952, s. 137.

[62] Porter, s. 196.

[63] Se Cawelti, s. 96.

[64] Se Anna Williams, Tillträde till den nya tiden. Fem berättelser om när Sverige blev modernt, Brutus Östlings Bokförlag Symposion 2002, s. 54 ff.

[65] Zygmunt Bauman, Vi vantrivs i det postmoderna, Daidalos 1998, s. 263. 